\title{
Estimation of forest cover restoration damaged by Siberian silkmoth using remote sensing data and maps
}

\author{
Elena Fedotova ${ }^{1,2}$ \\ ${ }^{1}$ Sukachev Institute of Forest SB RAS, FRC KSC SB RAS, Akademgorodok,50, b. 28, Krasnoyarsk, \\ 660036, Russian Federation \\ ${ }^{2}$ Siberian Federal University, Institute of Space and Information Technology, 26, Kirensky st., \\ Krasnoyarsk, 660074, Russian Federation
}

\begin{abstract}
The current state of the land cover has been estimated in the territories where in different years $(1885,1955,1995)$ the forests were damaged by Siberian silkmoth. Dark-needle taiga is restored through the change of tree species. In 20 years in areas of dark-needle taiga there are graminoid communities, in 60 years we have deciduous forests there, and in 130 - dark needle forests, but not everywhere.
\end{abstract}

\section{Introduction}

The Siberian silkmoth is one of the most dangerous pests of the taiga forest, since during the outbreaks it damages forests in the area of hundreds of thousands of hectares until death [1]. This pest is a constantly acting factor in coniferous stands of Siberia, which are restored after its attack slowly and badly. The greatest damage from silkmoth is for forests with Siberian fir and cedar (Siberian pine), which are less resistant to damage and do not regenerate needles after it has been eaten by silkmoth.

The restoration of forest cover after the defeat by the Siberian silkmoth is an important topic for study, and this is due to the fact that forests have enormous ecological and economic importance. The existing works in this field is quite contradictory. So, N.F. Reimers [2] conducted observations of forest restoration after silkmoth outbreak in the territory of the Irkutsk region and Buryatia and came to the conclusion about the successful resumption of cedar (in the absence of repeated fires). According to the observations in the Tomsk region, V.A. Dudin (1958) came to the conclusion that forest restoration went through a change of tree species. This conclusion is supported by the materials of later studies in the forests of the Tomsk region by Pavlova (2004) and A.A. Ageeva (2006). Thus, either this process has regional peculiarities, or a variety of factors influencing the restoration of cedar after silkmoth outbreak it leads to different results.

The process of the forest cover restoration can be described as a succession. Succession is a gradual, irreversible, directed change of some biocenoses (a historically formed set of animals, plants, fungi and microorganisms inhabiting a relatively homogeneous living space and connected among themselves by their surroundings) by others on the same territory under the influence of natural factors or in the result of human activity [3]. It is of 
considerable interest to analyze the current state of vegetation cover in the areas where the outbreaks of the Siberian silkmoth took place at different times, which allows us to evaluate the course of restorative succession.

Succession after the Siberian silkmoth outbreaks is often complex. The recovery stages depend on the climatic conditions, the frequency of fires in a given area, the presence of undamaged forests as seed sources, human activity. In the area of the dead dark coniferous forests, as shown by numerous observations, after about 10 years there are shrubs and deciduous forests. Most often, after changing the tree species for 100 years or more, dark coniferous forest appears again on this territory.

The author's goal is to illustrate this concept of forest cover restoration for three Siberian silkmoth outbreaks that took place at different times in the territory of Siberia.

\section{Study areas, Data and Methods}

In this paper we consider three areas of interest (fig. 1) :

- the valleys of the Malaya and Bolshaya Belaya rivers of the Eastern Sayan mountains (the Irkutsk region) [4]; the silkmoth outbreak took place in the 1980s of the 19th century and damaged cedar (Siberian pine) forests;

- the Ket-Chulym interfluve; south taiga in West Siberia; the outbreak of 1952-1957 [1]; dark coniferous forests were damaged;

- the Lower Angara area (the Krasnoyarsk Territory); dark coniferous forests were damaged during the outbreak in 1993-1996.

The tasks of remote sensing data processing and their joint analysis with various maps were:

- to identify the territories of dead and damaged forests after outbreak;

- to determine the actual state of the land cover.

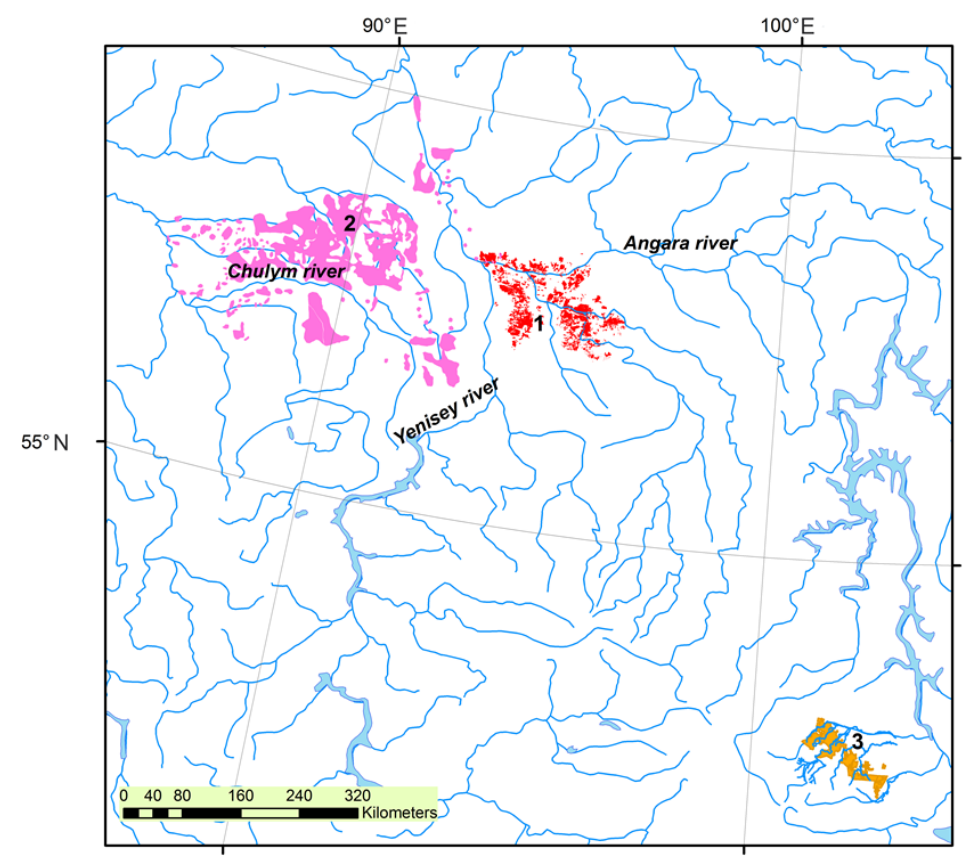


Fig. 1. Areas studied. 1 - Lower Angara area; 2 - Ket-Chulym interfluve; 3 - valley of Bolshaya Belaya river, East Sayan.

\subsection{Lower Angara area}

The main forest composition before silkmoth outbreak was fir, cedar, pine, larch and birch. The dead stands (mainly formed by fir) occupy a total area of 230 thousand hectares. They form several large continuous areas. Poorly damaged forests are located more mosaically.

The initial data for the analysis included:

- Landsat images acquired in 1989, 2000 and 2017;

- a map of damaged forests with three levels of damage, made in Forest Protection Center of the Krasnoyarsk Territory;

- a digital elevation model;

- a map of vegetation of the Russian Federation [5].

Using Landsat images of 1989 (before the outbreak) and 2001 (after the outbreak) and the map of dead and damaged forests with three levels of damage, the territories of the damaged and dead dark coniferous forests have been clarified. Further, these territories were analyzed using remote sensing data Landsat8 OLI of 2017 and the map [5] for each level of forest damage to identify actual land cover.

\subsection{Ket-Chulym interfluve}

As a result of the outbreak, which took place in 1952-1957, about 2.5 hectares of the taiga were damaged, about 1.5 million hectares of dark coniferous forests dried up, and in the territorie of dead trees in 1966, in most cases there was no satisfactory restoration of not only conifers, but also deciduous forests [1].

The initial data for these area are:

- a map of dead and damaged in 1952-1957 year forests made in Forest Protection Center of the Krasnoyarsk Territory;

- Landsat images (8 scenes for 2017, 2000 and 1978);

- a digital elevation model,

- a map of vegetation of the Russian Federation [5].

The map of dead and damaged forests was used as a mask to exclude territories outside silkmoth outbreak from the map of vegetation [5] and Landsat scenes. Landsat MSS, TM and OLI images with channels in visible, near-infrared and short-wave-infrared ranges were classified by the ISODATA method to define the land cover and enhance the map of vegetation.

\subsection{Valley of Bolshaya Belaya river, East Sayan}

The oldest of the considered Siberian silkmoth outbreaks occurred in the Eastern Sayan mountains in the Belaya River valley. According to [4], the beginning of large damages of cedar (Siberian pine) taiga in this region dates back to 1885 . The cedar forests in the investigated area, occupied a continuous strip stretching for several tens of kilometers in the direction of the loaches, have had a continuous character at altitudes from 700 to $1700 \mathrm{~m}$. In 1931, the area of damaged forests consisted of withered cedar plantings, burnt areas, with low birch and burnt areas in valleys of rivers.

For the study area the following data were used:

- a map of damaged Siberian cedar forests, compiled in 1931 (in the paper) in time of forest patology expedition [4];

- modern Landsat images of moderate spatial resolution; 
- a map of vegetation cover of the Russian Federation [5];

- a digital elevation model (DEM).

The paper map of dried cedar forests was scaned and georeferenced to a Landsat image. Landsat images of 1978 (Landsat MSS) and 2013 (Landsat8 OLI) with channels in visible, near-infrared and short-wave-infrared ranges were classified to define land cover types in the territory.

\section{Results and discussion}

\subsection{Study area in Lower Angara area}

Currently in this area, only $15 \%$ remained of dark coniferous forests, mainly in areas with a low level of damage (Table 1, Fig. 2). Deciduous, pine and larch forests account for $14 \%$. Mostly deciduous and mixed forests together are $27 \%$; mostly coniferous $-9 \%$ of the territory. Bare soils (mainly on fire scars) and graminoid communities occupy $1.7 \%$ and $32.5 \%$ respectively where dark coniferous forests were in large areas and heavily damaged or dead. Thus, the territory of the dead forests is represented in 20 years mainly by fire scars and graminoid communities with deciduous forests that were part of the primary mixed fir forest.

Table 1. Land cover types in the areas of Siberian silkmoth outbreaks

\begin{tabular}{|c|c|c|c|c|c|c|c|}
\hline $\begin{array}{c}\text { Years of } \\
\text { sikmoth } \\
\text { outbreak }\end{array}$ & $\begin{array}{c}\text { Dark- } \\
\text { needle } \\
\text { coniferous } \\
\text { forest }\end{array}$ & $\begin{array}{c}\text { Deciduous } \\
\text { and light- } \\
\text { needle } \\
\text { coniferous } \\
\text { forest }\end{array}$ & $\begin{array}{c}\text { Mainly } \\
\text { deciduous } \\
\text { forest }\end{array}$ & $\begin{array}{c}\text { Mixed } \\
\text { forest }\end{array}$ & $\begin{array}{c}\text { Mainly } \\
\text { coniferous } \\
\text { forest }\end{array}$ & $\begin{array}{c}\text { Graminoid } \\
\text { communuties }\end{array}$ & $\begin{array}{c}\text { Bare } \\
\text { soils }\end{array}$ \\
\hline 1885 & 58 & 16 & 5 & 5 & 2 & - & 1 \\
\hline $\begin{array}{c}1953- \\
1957\end{array}$ & 7 & 50 & 7 & 8 & 18 & - & \\
\hline $\begin{array}{c}1994- \\
1997\end{array}$ & 15 & 14 & 27 & & 9 & 32.5 & 1.7 \\
\hline
\end{tabular}

\subsection{Study area in Ket-Chulym interfluve}

In the territory of 2.5 million hectares of damaged forests, now dark coniferous forests account for $7 \%$, pine and deciduous forests $-50 \%$, mixed predominantly deciduous forests $-7 \%$, mixed forests $-8 \%$, mixed with the advantage of coniferous ones $-18 \%$ (Table 1 , Fig. 2). Dark coniferous forests are restored through the replacement of tree species (from deciduous birch and aspen to dark coniferous fir), and primarily in areas most closely located to undamaged dark coniferous stands. Large areas of dead woods are at the succession stage of deciduous forests. Since there was a large number of fires in the damaged forests, in these areas there is mainly deciduous forest now. The main condition for a more successful restoration of dark coniferous forests is the proximity to undamaged forests that are the source of seeds.

\subsection{Study area in Belaya River valley, East Sayan}

The total area of damaged forests is estimated at several hundreds of thousands of hectares, as it is written in [4] and as shows the results of paper map georeferensing and digitaizing. 


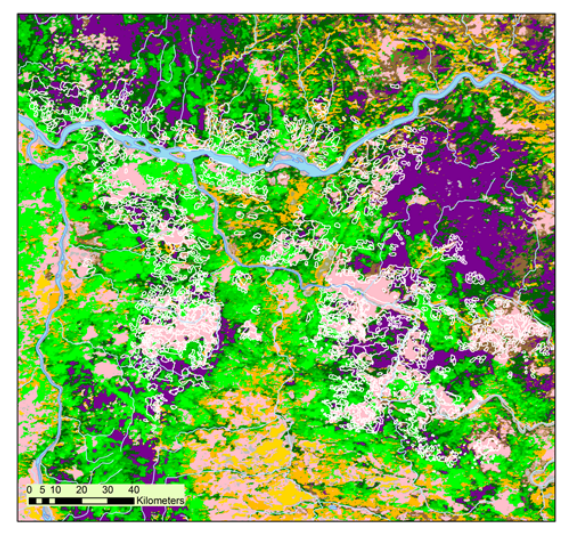

\section{A \\ Lower Priangarye}
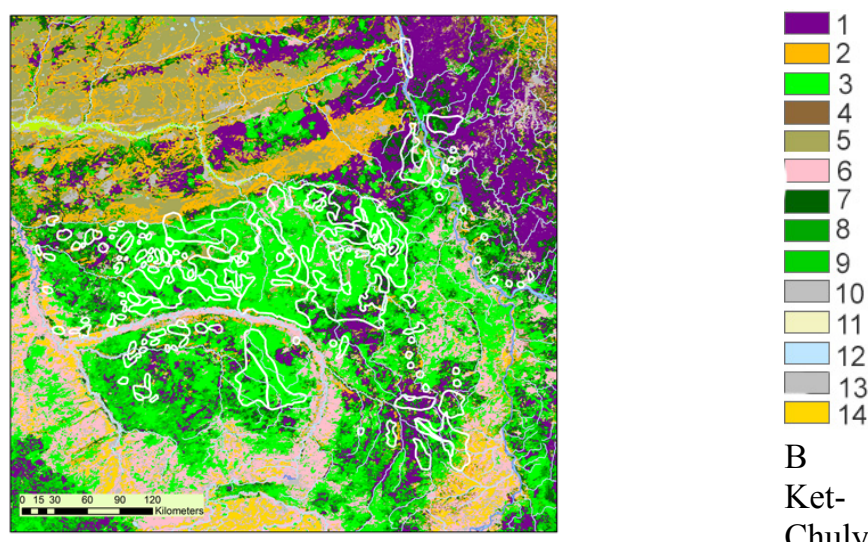

B

Ket-

Chulym

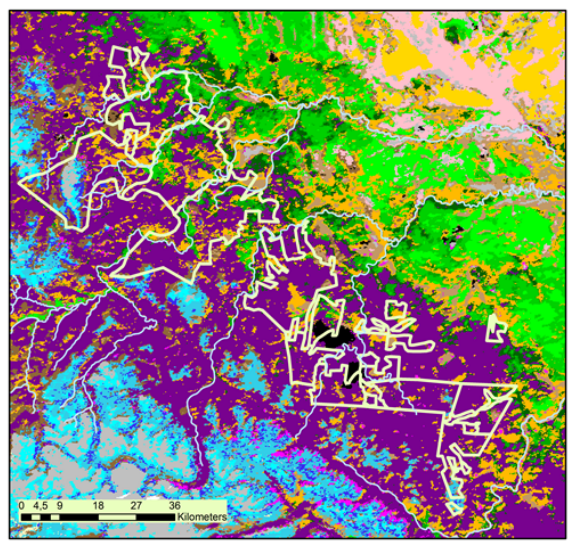

C

Belaya river

Fig. 2. Land cover types in the areas of interest: 1 - Evergreen Dark Needleleaf Forest, 2- Evergreen Light Needleleaf Forest, 3 - Deciduous Broadleaf Forest, 4 - Deciduous Needleleaf Forest, 5 Peatlands, 6 - Humid Grasslands, 7 - Broadleaf/Needleleaf Forest, 8 - Mixed Forest, 9 Needleleaf/Broadleaf Forest, 10 - Bare Soil and Rock, 11 - Steppe, 12 - Water bodies, 13 - urban area, 14 - Croplands 
As of 1978, according to classification results of Landsat images dark coniferous forests occupied $48 \%$ of the territory, that was as dead cedar in 1931. Table 1 and Figure 2 show the percentages of different land cover types in the dry cedar forests that have been defined, using the vegetation map [5] and results of Landsat images classification. Only 58\% is occupied by dark coniferous forests. The rest of the territory is occupied by pine, deciduous and mixed forests. Pine forests occupy the southern and south-western slopes, as the analysis with SRTM DEM shows.

A study of the succession process using GIS technologies can be useful for predicting the taiga restoration in the territory of the current Siberian silkmoth outbreak in the Yeniseisk district of the Krasnoyarsk Territory and adjacent territories (fig. 3). The area of dead forests is about 730 thousand hectares. Forests are damaged or dead in large areas, often limited by stands that are not food for the Siberian silkworm. Only in the east of the area there are not very large dark coniferous forests left intact, and in the west by the Yenisei Ridge.

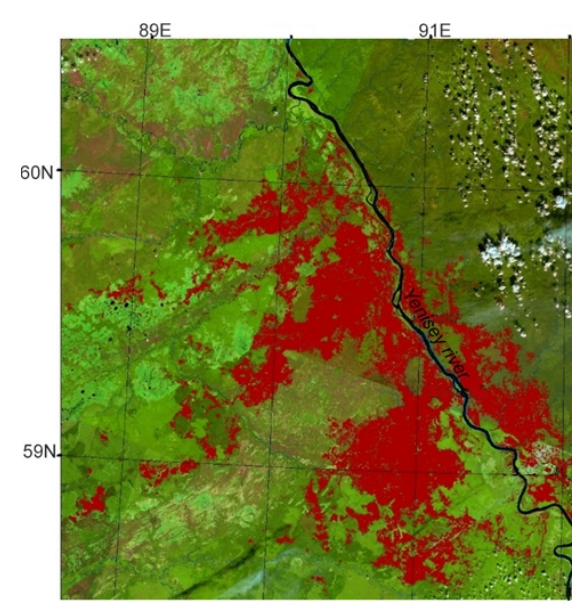

Fig. 3. Broken forests as a result of the outbreak Siberian silkworm in 2014-2017

In 20-30 years, the areas of the dead forests will be in the state of graminoid communities, and if the confluence of circumstances succeeds, one can expect that in this territory deciduous (mainly birch) forests will have grown by 2080, under the canopy of which the fir stands will have been restored.

The reported study was funded by Russian Foundation for Basic Research (No.18-47-242002), Government of Krasnoyarsk Territory, Krasnoyarsk Regional Fund of Science, to the research project: «The development of technology for creating intelligent information systems of object-oriented monitoring of territories based on remote sensing data».

\section{References}

1. V.V. Kuzmichev,V.P. Cherkashin, M.A. Korets, I.A. Michailova, Lesovedeniye, 4, 8-14 (2001) (in Russian)

2. N.F. Reymers, Trudy po lesnomu chozyaistvu Sibiri - Works about forestry in Siberia, 4, 255-261 (1958) (in Russian)

3. http://www.grandars.ru/shkola/geografiya/sukcessiya.html

4. V.A. Povarnitsin, Angarskaya lesnaya expediciya 1931 - Angarsk forest expedition (1934) (in Russian)

5. The Map of vegetation cover of Russia http://smiswww.iki.rssi.ru/default.aspx?page=317 